\title{
Analysis of the Effects of two Gamified Emotional Education Software's in Emotional and Well-being Variables in Spanish Children and Adolescents
}

\author{
https://doi.org/10.3991/ijet.v13i09.7841 \\ Agnès Ros-Morente, Enric Cabello Cuenca, Gemma Filella-Guiu( $\left.{ }^{(}\right)$ \\ University of Lleida, Lleida, Spain \\ gfilella@pip.udl.cat
}

\begin{abstract}
The aim of the present research is to explore the differences among emotional and well-being variables in primary and secondary education students after undergoing the software's Happy 8-12 and Happy 12-16 during an academic course. These innovative software's are focused in the training of the basic emotional competences. The study has a pre-post quasi-experimental design with a control group. A total of 574 primary education students and 903 secondary education students participated in the study. Results show that the training of the emotional competences with novel methods, such as gamified software's, improves the emotional competences, reduces anxiety and enhances academic achievement in a sample of Spanish students.
\end{abstract}

Keywords-Gamification, Happy, emotional education, software's.

\section{Introduction}

During the last decades there has been a renewed interest in the study of the emotional and well-being variables in the students ${ }^{1-6}$. This concern is due to the amount of violent episodes in scholar centres, which is everytime higher. The latest data, for example, shows that about one of every four children has suffered bullying, and that up to a 15 per cent of the students has suffered violence ${ }^{7,8}$. Additionaly, the distress induced by the violent phenomena has exponentially increased ${ }^{9}$.

The scientific community has emphasized that this kind of phenomena carry serious immediate and long-term negative effects for the well-being of the students, thereby hampering a proper learning process ${ }^{2,10,11}$. Also, empirical evidence reveals that suffering violent situations in the peer group has a devastating effect for the personal development and academic achievement of the victim. More specifically, the victim can develop severe anxiety symptoms and/or a threatening view of the scholar environment $^{12-15}$. For this reason, basic emotional competences have been considered a crucial factor for the improvement of social coexistence and well-being of students, 16-18. Thus, it is undeniable that a pupil with strong emotional competences and a successful emotional management will feel and develop in a better fashion, helping the improvement of school coexistence ${ }^{16,19-23}$. 
During the last years several new programs and methods have been suggested, proving that new technologies are an effective way to improve emotional competences and thus, facilitate the personal and collective well-being of students, for example $^{24-30}$, among many others. Happy 8-12 and Happy 12-16 are two novel gamified programs for emotional education which have shown its positive effects.

\subsection{Happy 8-12 and Happy 12-16}

Happy 8-12 and Happy 12-16 are two software's designed to train emotional competences in everyday life situations as well as in conflict situations among peers in the elementary school level and high school level, respectively.

These software's aim to train emotional competences of children and adolescents by recognizing and regulating their emotions while being in a conflict situation. At the same time, the student also learns the most adaptive and assertive response to that situation. This whole process is carried out through 4 basic and progressive steps (see the figure below).

This video game software's consist of 25 conflicts which are contextualised in different settings, such as the playground, the hall or even at home. The roles of the player (student) during the conflict can be three: a) the person that shows an aggressive behaviour, b) the person that suffers the aggression, and c) the bystanders. In each one of the conflicts the process of emotion regulation is trained in the following way (see the figure 1).

Although the competences that are trained with these software's are the ones described by the Research Group in Psychopedagogical Orientation (GROP), they are mainly based in the cognitive-linguistic abilities and the development of the six moral stages of Piaget-Kohlberg. Also, the emotion regulation strategies included in the software's stem from the model developed by Gross in 2007.

\begin{tabular}{|c|c|c|c|}
\hline \multicolumn{4}{|c|}{ EMOTIONAL REGULATION PROCESS } \\
\hline $1^{\text {ST }}$ STEP & $2^{\mathrm{ND}} \mathrm{STEP}$ & $3^{\mathrm{RD}} \mathrm{STEP}$ & $4^{\text {TH }}$ STEP \\
\hline $\begin{array}{l}\text { EMOTIONAL } \\
\text { AWARENESS }\end{array}$ & $\begin{array}{l}\text { TRAFFIC } \\
\text { LIGHT }\end{array}$ & $\begin{array}{l}\text { REGULATION } \\
\text { STRATEGIES }\end{array}$ & $\begin{array}{l}\text { ASSERTIVE } \\
\text { RESPONSE }\end{array}$ \\
\hline $\begin{array}{c}\text { Become aware } \\
\text { of what you are } \\
\text { feeling }\end{array}$ & $\begin{array}{c}\text { STOP } \\
- \\
\text { BREATH } \\
- \\
\text { THINK }\end{array}$ & $\begin{array}{l}\text { 1.Behavioural and Cog- } \\
\text { nitive Distraction } \\
\text { 2. Show the Emotions: } \\
\text { Talk to a friend, write to } \\
\text { your friends... } \\
\text { 3. Ask for help } \\
\text { 4. Change your } \\
\text { thoughts } \\
\text { 5. Find a solution } \\
\text { 6. Ask for help to an } \\
\text { adult }\end{array}$ & $\begin{array}{c}\mathrm{N} \text { (Name) } \\
- \\
\mathrm{E} \text { (Emotion) } \\
- \\
\mathrm{M} \text { (Motive) } \\
- \\
\mathrm{O} \text { (Objective) }\end{array}$ \\
\hline
\end{tabular}

Fig. 1. Emotion regulation process of Happy software's (http://emotionalsocialgames.blogspot.com.es/). 




Fig. 2. Image of "traffic light" process in the software.

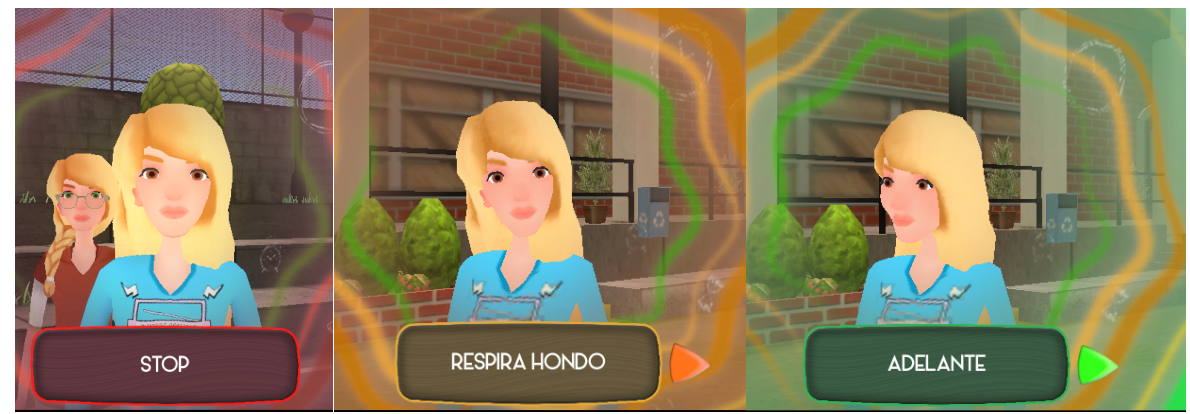

Fig. 3. Image of "traffic light" process in the software.

As Figure 2 shows, the very first step is recognizing, feeling and experimenting the emotion. Being aware of the emotions that take place in a certain situation enables the individual to be aware of the intensity and durability of these emotions. Each one of these aspects is fundamental in order to properly use strategies to regulate our emotions and adapt to our environment.

The second step refers to the "traffic light". In this step, the software induces the students to stop and breathe before finding a solution for the situation of the conflict. In this way, the student reduces his anxiety, enabling a better functioning of the neocortex.

The third step involves the regulation of the emotions. According to authors, emotion regulation is the capacity of enhance, maintain or reduce the emotional response, including its expression ${ }^{31,32}$. Based on the theory of Gross and Thompson ${ }^{33}$ and adapted to the reality of the students, the strategies that appear in the software's can be viewed in Fig 1., which range from asking for help to finding a solution.

In the final step, the student can choose from four options: a passive response, an agressive response, a non-related response or an assertive response (the best one). The 
choice of an assertive response with a NEMO (see Fig 1.) procedure ensures an answer that respects both the student and the other part implicated in the situation.

In order to ensure the efficacy of the software's it is not only needed that the students follow the aforementioned process, but it also requires the support of a teacher. Additionally, sessions to play should be organised weekly for the institution (ideally 1-2 hours per week).

Thus, Happy 8-12 and Happy 12-16 are designed with the objective or going beyond entertainment or purely acquire knowledge, it gives the opportunity to interactively work with students and become more autonomous and flexible.

\section{$1.2 \quad$ Objectives}

In the present article we aim to describe and explore the characteristics and effects of the emotional and social competences in two samples of Spanish samples. More specifically, we aim to analyse the effects of the software's Happy 8-12 and Happy 12-16 in students of different ages.

\section{Method}

\subsection{Subjects}

The sample of the present study was composed by two groups: a group of students of elementary school and a group of students of secondary education schools. At the same time, both groups included schools which underwent the experimental condition and other schools which constituted the control group.

Elementary school student's subsample. It was composed by 574 students (301 boys, $52.4 \%$, and 273 girls, $47.6 \%)$. All the students were in $5^{\text {th }}(\mathrm{n}=278 ; 48.4 \%)$ and $6^{\text {th }}(n=296 ; 51.6 \%)$ grades. Participants were 10.53 years old in average, with a standard deviation of .662. The experimental group had 351 students of 6 different schools ( $62 \%$ of the total). The control group had 223 students of 4 other schools ( $38 \%$ of the total), which participated in a voluntary fashion. There were no statistically significant differences regarding sex or course among the two groups, which guaranteed the homogeneity of the two groups in order to analyse the objectives of the study.

Secondary educations student's subsample. It consisted of 903 students. 471 of them were males $(52.2 \%)$ while $432(47.8 \%)$ were females. All the students of this group were in $1^{\text {st }}(\mathrm{n}=440 ; 48.7 \%)$ and $2^{\text {nd }}(\mathrm{n}=463 ; 51.3 \%)$ grades of compulsory secondary education. The average age of the students was 12.63 , with a standard deviation of .608. A total of 472 students of 7 different high-schools $(52.3 \%$ of the total) composed the experimental group. The control group was constituted by 431 students of 4 voluntary centers $(47.7 \%$ of the total). In the analyses, no statistically significant differences among groups were found. 


\subsection{Instruments}

Although the variables assessed in the study were identical for the groups of elementary education and secondary education, it was only logical to use instruments that were consistent with the age of the participants. The differences among the instruments were minimal and in the majority of cases, there were the same instrument but in different version. This enabled the authors to guarantee the possibility of stablishing an equitable comparative among the two groups of participants.

Elementary school instruments: Emotional Development Questionnaire $\left(\mathrm{QDE}^{34}(\mathrm{GROP})\right)$. This self-informed instrument taps the principal concepts regarding emotional education (Research Group in Psychopedagogical Orientation (GROP) ${ }^{35,36}$. It comprises five subscales which assess Emotional Awareness, Emotion Regulation, Emotional Autonomy, Social Competence and Life's Competences. A score for each subscale and a total one can be extracted.

Stait-Trait Anxiety Inventory for Children-Spanish Version (STAIC ${ }^{38}$. This questionnaire taps within two individual scales the levels of anxiety that an individual feels at a certain moment (Anxiety -State) and in general (Anxiety-Treat). Each one of the scales has 20 simple items destined to assess the levels of anxiety of the child. For this study, we used the 20 items of the state scale of the Spanish version ${ }^{38}$ to assess the levels of anxiety that children had at the moment of evaluation (Anxiety-State).

Finally, academic performance from each participant was gathered with the marks of the compulsory subjects of the students.

Secondary school instruments: Emotional Development Questionnaire for secondary school (QDE SEC ${ }^{39}$. This instrument, in a practically identical way as the adapted version for elementary school, assesses the emotional education competences described by Bisquerra ${ }^{36}$. As it happened in the previous case, the instrument showed an adequate internal consistency, with an Alpha coefficient of 0.83 .

Stait-Trait Anxiety Inventory (STAI ${ }^{37,38,40}$ ). It has two independent scales to assess Anxiety-State and Anxiety-Trait. In this case, the instrument showed an excellent internal consistency with an alpa of Cronbach of 0.93 .

Academic performance was evaluated with the average marks of all the subjects: biology and geology, geography and history, Spanish language and literature, English language and literature, physical education, ethics, and three different subjects that students could choose during the academic course.

\subsection{Procedure}

First of all, in order to ensure that the project was implemented in an optimal way, the research team contacted the Department of Education in Spain. The study was presented and studied and it finally achieved the permission of the Government's Department of Education. Afterwards, there was a first contact with those schools who were willing to participate in a voluntary level in order to explain them in detail the research project related with the two software's (Happy 8-12 and Happy 12-16). Given the novelty of the software's and the interest in an extensive analysis of its effects, two researchers of the team oriented, guided and trained the teachers and 
management teams of each one of the experimental schools participating for the administration of the software's. The training on Happy 8-12 or Happy 12-16 (depending on the age and course of the participants) was done for over 30 hours. After the training, the pretest protocol was administered. Then, those centres of the experimental condition followed the Happy 8-12 or 12-16 programs and, finally, all the data of the students was collected with the posttest protocol. The design that this research underwent was a quasi-experimental design with pretest and posttest and a control group.

\section{$3 \quad$ Results}

Data was processed and analyzed using the SPSS 20.0 software package. Descriptive data of the quantitative variables with the analysis of the comparison pretest and posttest of both subsamples of the study can be seen in Tables 1 and 3, respectively. Descriptive statistics of the demographic variables were obtained in the very beginning of the study in order to analyse and compare the homogeneity of the sample. Results showed that subsamples were balanced and showed no relevant statistical differences.

In order to assess the effect of the software's Happy 8-12 and Happy 12-16 in the experimental group, an analysis of variance (ANOVA) with intersubject factor and intrasubject factor was carried out.

In the sample of the elementary school students, results show that the scores of $\mathrm{CDE}$ in the experimental group increased after the administration of the video game Happy 8-12, indicating the improvement of the emotional competences at a global level. This change was not observed in the control group. As it can be seen in Table 1, these differences were statistically significant for the global scale of CDE, although the effect size, evaluated with the F index, was not high. This can be attributed to the stable nature of the emotional competences.

Table 2 shows the average values for each group in the initial moment of the assessment and after the intervention with the video game Happy 12-16 for the subsample of secondary education. Additionally, it shows the results obtained by the general lineal model carried out for each one of the variables evaluated in the study.

The results of the global scale of QDE-SEC for the secondary school subsample were analysed for both the global scale and for each one of the subscales. Results show that, just as it happened with the younger students, the scores increased significantly in the experimental group in a general fashion after the intervention with Happy 12-16. This improvement in the emotional competences was not observed in the control group. However, as it happened with the students of younger ages, the general scale did not show all these changes, resulting in a statistically non-significant number. For this reason, it was necessary to study at a statistical level each one of the scales of the instrument individually. This second analysis, as it can be seen in Table 2 , shows that there are three scales which show statistically significant differences between the experimental and the control groups after the implementation of the program: emotional awareness (F (7.71); $p<0.01)$, emotional autonomy $(F(6.02) p<0.01)$ 
Table 1. Average values of the results for the control $(n=223)$ and experimental groups $(n=351)$ and for the tests $(n=574)$ in the sample of elementary school students.

\begin{tabular}{|c|c|c|c|c|c|}
\hline Test & Group & \begin{tabular}{|c|} 
Pre Happy 8- \\
12 score \\
\end{tabular} & \begin{tabular}{|l} 
Post Happy \\
8-12 score \\
\end{tabular} & $\begin{array}{c}\text { Average change } \\
\text { pre/post }\end{array}$ & $\begin{array}{c}\text { Average change } \\
\text { F; p-value }\end{array}$ \\
\hline \multirow{2}{*}{ CDE Total } & Experimental & 6.85 & 6.91 & -0.06 & \multirow{2}{*}{$5.81 ; .16$} \\
\hline & Control & 7.14 & 7.02 & 0.12 & \\
\hline \multirow{2}{*}{$\begin{array}{l}\text { CDE Emotional } \\
\text { Awareness }\end{array}$} & Experimental & 7.38 & 7.39 & 0.01 & \multirow{2}{*}{$.47 ; .703$} \\
\hline & Control & 7.61 & 7.52 & -0.09 & \\
\hline \multirow{2}{*}{$\begin{array}{l}\text { CDE Emotion } \\
\text { Regulation }\end{array}$} & Experimental & 6.18 & 6.33 & 0.15 & \multirow{2}{*}{$3.34 ; .02$} \\
\hline & Control & 6.12 & 6.15 & 0.03 & \\
\hline \multirow{2}{*}{ CDE Autonomy } & Experimental & 6.73 & 6.81 & 0.08 & \multirow{2}{*}{$1.74 ; .16$} \\
\hline & Control & 6.49 & 6.60 & 0.11 & \\
\hline \multirow{2}{*}{$\begin{array}{l}\text { CDE Social Compe- } \\
\text { tences }\end{array}$} & Experimental & 6.86 & 7.05 & 0.19 & \multirow{2}{*}{$1.45 ; .23$} \\
\hline & Control & 6.66 & 6.64 & -0.02 & \\
\hline \multirow{2}{*}{$\begin{array}{l}\text { CDE Life Compe- } \\
\text { tences }\end{array}$} & Experimental & 7.76 & 7.75 & -0.01 & \multirow{2}{*}{$.13 ; .94$} \\
\hline & Control & 8.08 & 7.76 & 0.03 & \\
\hline \multirow{2}{*}{ STAIC } & Experimental & 60.71 & 42.72 & 17.99 & \multirow{2}{*}{$9.33 ;<.001$} \\
\hline & Control & 43.31 & 34.74 & 8.57 & \\
\hline \multirow{2}{*}{$\begin{array}{l}\text { Academic achieve- } \\
\text { ment (maths) }\end{array}$} & Experimental & 6.50 & 6.53 & 0.03 & \multirow{2}{*}{$.001 ; .97$} \\
\hline & Control & 6.54 & 6.55 & 0.01 & \\
\hline \multirow{2}{*}{$\begin{array}{l}\text { Academic achieve- } \\
\text { ment (Spanish) }\end{array}$} & Experimental & 6.40 & 6.56 & 0.12 & \multirow{2}{*}{$5.713 ; .02$} \\
\hline & Control & 6.83 & 6.91 & 0.03 & \\
\hline \multirow{2}{*}{$\begin{array}{l}\text { Academic achieve- } \\
\text { ment (English) }\end{array}$} & Experimental & 6.62 & 6.77 & 0.15 & \multirow{2}{*}{$.303 ; .58$} \\
\hline & Control & 6.37 & 6.69 & 0.32 & \\
\hline
\end{tabular}

Table 2. Average values of the results for the control $(n=)$ and 431 experimental groups $(n=472)$ and for the tests $(n=903)$ in the sample of secondary school students.

\begin{tabular}{|c|c|c|c|c|c|}
\hline Test & Group & $\begin{array}{l}\text { Pre Happy 8- } \\
12 \text { score }\end{array}$ & $\begin{array}{l}\text { Post Happy } \\
8-12 \text { score }\end{array}$ & $\begin{array}{c}\text { Average change } \\
\text { pre/post }\end{array}$ & $\begin{array}{c}\text { Average change } \\
\text { F; p-value }\end{array}$ \\
\hline \multirow{2}{*}{ QDE SEC Total } & Experimental & 6.09 & 6.05 & 0.04 & \multirow{2}{*}{$3.77 ; .52$} \\
\hline & Control & 6.26 & 6.18 & 0.08 & \\
\hline \multirow{2}{*}{$\begin{array}{l}\text { QDE SEC Emotional } \\
\text { Awareness }\end{array}$} & Experimental & 7.38 & 7.57 & 0.19 & \multirow{2}{*}{$7.71 ; .01$} \\
\hline & Control & 7.24 & 7.32 & 0.07 & \\
\hline \multirow{2}{*}{$\begin{array}{l}\text { QDE SEC Emotion } \\
\text { Regulation }\end{array}$} & Experimental & 5.12 & 5.06 & 0.06 & \multirow{2}{*}{$.17 ; .68$} \\
\hline & Control & 5.22 & 5.25 & 0.03 & \\
\hline \multirow{2}{*}{ QDE SEC Autonomy } & Experimental & 5.82 & 6.01 & 0.19 & \multirow{2}{*}{$6.02 ; .01$} \\
\hline & Control & 5.96 & 6.02 & 0.06 & \\
\hline \multirow{2}{*}{$\begin{array}{l}\text { QDE SEC Social } \\
\text { Competence }\end{array}$} & Experimental & 5.96 & 5.97 & 0.01 & \multirow{2}{*}{$.20 ; .65$} \\
\hline & Control & 6.13 & 6.03 & 0.10 & \\
\hline \multirow{2}{*}{$\begin{array}{l}\text { QDE SEC Life's } \\
\text { Competences }\end{array}$} & Experimental & 6.30 & 6.54 & 0.24 & \multirow{2}{*}{$26.25 ;<.001$} \\
\hline & Control & 6.50 & 6.77 & 0.17 & \\
\hline \multirow{2}{*}{ STAI-E } & Experimental & 43.71 & 44.70 & 0.99 & \multirow{2}{*}{$5.02 ; 0.02$} \\
\hline & Control & 42.67 & 43.22 & 0.55 & \\
\hline \multirow{2}{*}{$\begin{array}{l}\text { Academic achieve- } \\
\text { ment }\end{array}$} & Experimental & 5.89 & 6.07 & 0.18 & \multirow{2}{*}{$33.08 ;<.001$} \\
\hline & Control & 5.87 & 5.98 & 0.11 & \\
\hline
\end{tabular}


and life's competences ( $\mathrm{F}(26.25) ; \mathrm{p}<.001)$. In a different manner, social competences and the emotion regulation scale did not show any significant changes, which can explain the non-significant value of the global scale.

In reference to the results of STAIC, both groups (control and experimental) showed an important decrease in the levels of anxiety-state in the elementary school students. However, the levels of the experimental group decreased more substantially after the administration of Happy 8-12 (see Table 1). This fact was highly statistically significant, showing a 17.99 points of different between the control and the experimental groups $(\mathrm{F}=9.33 ; \mathrm{p}<0.001)$. Surprisingly enough, in the sample of teenagers, the effect was completely opposite since anxiety seems to raise in a significant way ( $\mathrm{F}$ (5.02); $\mathrm{p}=.002)$ ).

Regarding the academic achievement, younger students showed a statistically significant mprovement after the training with the video game Happy 8-12 (see Table 1). This same results were more notable in the sample of secondary school students who, moreover, showed an important increase in their global academic performance (see Table 2).

\section{Discussion}

Under the premise that emotional and social competences improve the development and well-being of students, this study shows the effects of the implementation of an educative video game (Happy) in two different populations: a group of primary school students (Happy 8-12), and another group of secondary education students (Happy 12-16).

Regarding the results of the primary school students, the study shows that, as it was hypothesized, the training with the innovative tool of Happy 8-12 video game led to a statistically significant improvement in both emotional and social competences among students. Moreover, the scale of emotional development, which is the most sensible to changes, showed a high statistically significant increase. Although other scales like regulation showed less change, it is important to stress the fact that this kind of changes require a much slower and longer processes, as it has been repeatedly proven in previous findings ${ }^{41}$. Thus, although the software's can produce significant improvement and measurable changes that have important implications at a practical level, a longer training would be needed in order to modify thoughts or beliefs that are really anchored in the subject. The global scale, for example, although it was not statistically significant, showed a discrete learning effect after the administration of Happy. This shows that this kind of variables may greatly benefit from an additional long-term measurement in the future.

The effect of the video game in the group of adolescents proved to be slightly different. In this case, it is important to note the effects of Happy 12-16 in emotional awareness. This can be explained by the natural process of acquisition of this kind of competences and it can be taken as a sign of improvement. In this sense, it is difficult that an individual improves the capacity of regulating emotions if emotional awareness does not take place properly. Different to what happens to the younger group of 
students, this fact is especially visible in the group of adolescents given the total mastery of language and cerebral maturity.

The importance of the developmental stage is also observable in the life's competences and the emotional autonomy. Both scales showed a significant improvement in the group that received the training with Happy 12-16. These competences, linked with aspects such as self-esteem and those skills that enhance a proper adjustment to the environment, resulted very sensible to the implemented software to the teenagers. Just as it happened in the case of emotional awareness and as it has been explained, these competences can be considered previous and needed for the posterior development and improvement of the competences of a more complex and stable nature such as emotion regulation or social skills.

Another interesting effect of the software was the statistically significant decrease of the levels of anxiety state of those students that received the training with Happy. At a practical level, for the youngest students, anxiety decreased in a very notable manner, resulting in a very high statistically significant change in the posttest evaluation. These results are consistent with pervious literature, which indicates that a better management of emotional competences also improves the well-being of the students $^{42,43}$. Curiously enough, in a different way, the levels of anxiety-state of the secondary education students increased in the posttest evaluation in both control and experimental groups. This fact supports previous results that indicate that anxiety is, in many cases, inherent to different treats and symptomatology present during adolescence and this moment in vital development of every individual ${ }^{44,45}$. Additionally, improving emotional awareness also brings a deeper understanding of one's emotions, which can also make the adolescent more aware of his or her anxiety states. This fact suggests the need of preventing anxiety in those students who are in this age group $^{42,43}$.

Regarding academic achievement, there was a clear unanimity among both group of students. In this sense, the experimental groups improved their academic performance in a significant way. However, academic results were gathered right after the intervention with the software. A more long-term evaluation would possibly show an even more significant and steady change in the academic achievement.

All in all, the educative video game Happy has proved to be a promising tool which enables both students and professionals detect the initial level of emotional and well-being competences in order to train them to achieve a proper and adaptive management. This, at the same time, would enhance a major prevention for different conflicts that may exist in the scholar environment, or in everyday life. This work has proved that a software or gamified program, as is the case of Happy in his two versions (8-12 and 12-16) can be adapted to different group of ages and casuistry.

Future research in the field should evaluate these changes in the long term in order to ensure the endurance of the effect of the software. In fact, investigations in the future would greatly benefit from additional long-term measures that might also enable researchers to assess the sustainability of statistically significant acquired competence-improvements. It is undeniable, however, that motivation and eagerness from students is much higher than in other conventional programs and its effects are similar or even higher. Additionally, working with teachers and other professionals and en- 
Paper-Analysis of the Effects of two Gamified Emotional Education Software's in Emotional and Well...

suring their familiarization with the Happy software's may result in even higher improvement.

\section{$5 \quad$ References}

[1] Fernandez-Berrocal, P., Alcaide, R., Extremera, N., \& Pizarro,D. (2006). The role of emotional intelligence in anxiety and depression among adolescents. Individual Differences Research, 4 (1), 16-27.

[2] Filella, G., Cabello, E., Pérez-Escoda, A. \& Ros-Morente, A. (2016). Evaluación del programa de Educación Emocional "Happy 8-12" para la resolución asertiva de conflictos entre iguales. Electronic Jorunal of Research in Educational Psychology, 14 (3), 582-601. https://doi.org/10.14204/ejrep.40.15164

[3] Filella, G. \& Rueda, P. (2015). Aprèn a resoldre conflictes jugant. Videojoc Happy 12- 16. Trabajo presentado en las XI Jornades Maria Rúbies de Recerca i Innovació Educatives. E1 joc com a eina educativa en infants i adolescents. Experiències, vivències i recerca educativa. Lleida.

[4] Mayer, J., Roberts, R., \& Barsade, S. (2008). Human abilities: Emotional intelligence. Annual Review of Psychology., 59, 507-536. https://doi.org/10.1146/annurev.psych.59. $\underline{103006.093646}$

[5] Pena, M., Extremera, N. \& Rey, L. (2016). Las competencias emocionales: material escolar indispensable en la mochila de la vida. Revista Padres y Maestros/ Journal of Parents and Teachers. 368, 6-10. https://doi.org/10.14422/pym.i368.y2016.001

[6] Rueda,P., Cabello, E., Filella, G. \& Vendrell, C. (2016). El programa de educación emocional Happy 8-12 para la resolución assertiva de conflictos. Tendencias Pedagógicas, 28, 153-166. https://doi.org/10.15366/tp2016.28.011

[7] Craig, W., Harel-Fisch, Y., Fogel-Grinvald, H., Dostaler, S., Hetland, J., Simons-Morton, B. \& Pickett, W. (2009). A cross-national profile of bullying and victimization among adolescents in 40 countries. International journal of public health, 54, 216-224. https://doi.org/10.1007/s00038-009-5413-9

[8] Gabarda,V. (2014) Bullying en el aula: Aprende que tipos de bullying existen, cuáles son los factores de riesgo y cómo detectarlo. Universidad Internacional de Valencia. 1, 108.11 .

[9] Save the Children (2015). Violencia contra la infancia, hacia una Estrategia Integral. Madrid. Recuperado de https://www.savethechildren.es/publicaciones/violencia-contra-lainfancia-hacia-una-estrategia-integral

[10] Wang, W., Vaillancourt, T., Brittaing, H., McDougall, P., Kygsman, A., Smith, D., Cunningham, C.E., Haltigan, J.D., \& Hymel, S. (2014). School Climate, Peer Victimization, and Academic Achievment: Results from a multi-Informant Study. School Psychology Quarterly, 29 (3), 360-377. https://doi.org/10.1037/spq0000084

[11] Rueda, P., Filella, G. \& Ros, A. (in press). La resolución asertiva de conflictos con un programa de Educación Emocional. Bordón.

[12] Caballo,V., Arias,A., Calderero,M., Salazar, I. \& Irurtia, M. (2011). Acoso escolar y ansiedad social en niños (I): Análisis de su relación y desarrollo de nuevos instrumentos de evaluación. Behavioral Psychology/Psicología Conductual, 19, 3, 591-609.

[13] Cerezo, F. (2008). Acoso escolar. Efectos del bullying. Boletín de la Sociedad de Pediatría de Asturias, Cantabria, Castilla y León; 48, 353-358.

[14] Martorell, C., González, R., Rasal.P. \& Estellés,R. (2009). Convivencia e inteligencia emocional en niños en edad escolar. European Journal of Education and Psychology, 2, 69-78. https://doi.org/10.30552/ejep.v2i1.18 
Paper-Analysis of the Effects of two Gamified Emotional Education Software's in Emotional and Well...

[15] Pérez-Fuentes., Gázquez,J., Molero. M. \& García, M. (2011). Rendimiento académico y conductas antisociales y delictivas en alumnos de Educación Secundaria Obligatoria. International Journal of Psychology and Psychological Therapy, 11, 401-4012.

[16] Extremera, N. \& Fernández-Berrocal, P. (2003). La inteligencia emocional en el contexto educativo: hallazgos científicos de sus efectos en el aula. Revista de Educación, 332, 97 116.

[17] Pérez-Escoda, N., Filella, G., Soldevila, A. \& Fondevila, A. (2013). Evaluación de un programa de educación emocional para profesorado de primaria. Educación XXI, 16, 233254.

[18] Romera, E., Rodríguez, S. \& Ortega, R. (2015). Childrens perceptions of bullying among peers through the use of graphic representation. Cultura y Educación: Revista de teoría, investigación y práctica, 27 (1), 158-185. https://doi.org/10.1080/11356405.2015.1006850

[19] Blair,C. \& Raver,C (2015). School readiness and self-regulation: A developmental psychobiological approach. Annual Review of Psychology, 66, 711-731. https://doi.org/10.1146/annurev-psych-010814-015221

[20] Pérez-Escoda, N., Filella, G., Bisquerra, R. \& Alegre, A. (2012). Desarrollo de la competencia emocional de maestros y alumnos en contextos escolares. Electronic Journal of Research in Educational Psychology, (10)3/ 1183-1208.

[21] Miñaca-Laprida, M.I., Hervás, M., \& Laprida-Martín, I. (2013) "Análisis de programas relacionados con la Educación Emocional desde el modelo propuesto por Salovey y Mayer". RES: Revista de Educación Social, 17, 1-17.

[22] Ortega, R. (2006). "La convivencia: un modelo de prevención de la violencia". En A. Moreno y M.P. Soler (Coord.). La convivencia en las aulas, problemas y soluciones. Madrid: Ministerio de Educación y Ciencia.

[23] Pena, M. \& Repetto, E. (2008). Estado de la investigación en España sobre Inteligencia Emocional en el ámbito educativo. Revista Electrónica de Investigación Psicoeducativa, $15,6(2)$ 400- 420.

[24] Agulló, MJ., Filella, G., Soldevila, A. \& Ribes, R. (2011). Evaluación de la educación emocional en el cicló medio de Educación Primaria. Revista de Educación, 354, 347-349.

[25] Güell, M., y Muñoz, J. (2003). Educación emocional. Programa para la educación secundaria postobligatoria. Barcelona: Praxis-Wolters Kluwer.

[26] López-Cassà, E. (2003). Educación emocional. Programa para 3-6 años. Barcelona: Praxis.

[27] Pascual, V. \& Cuadrado, M. (2001). Educación emocional: programa de actividades para Educación Secundaria Obligatoria. Barcelona: CISS-PRAXIS.

[28] Renom, A. (2003). Educación emocional. Programa para educación primaria (6-12 años). Barcelona: Praxis.

[29] Monjas, I. (1999). Programa de enseñanza de habilidades de interacción social para niños y niñas en edad escolar. Madrid: CEPE.

[30] Vallés, A. \& Vallés, C. (1999). Desarrollando la inteligencia emocional. Madrid: EOS.

[31] Eisenberg, N. (2000). Emotion, regulation, and moral development. Annual review of psychology, 51(1), 665-697. https://doi.org/10.1146/annurev.psych.51.1.665

[32] Gross, J. (2007). Handbook of emotion regulation. New York: Guillford Press.

[33] Thompson, R. A., \& Meyer, S. (2007) The socialization of emotion regulation in the family. In: Gross J, editor. Handbook of emotion regulation. New York: Guilford.

[34] López Cassá, E. \& Pérez-Escoda, N. (2010). Les competències emocionals a l'alumnat de primària. Comunicació presentada en les VI Jornades d'Educació Emocional: "Emocions positives i benestar".

[35] Bisquerra, R. (2000). Educación emocional y bienestar. Barcelona: Praxis.

[36] Bisquerra, R. \& Pérez, M. (2007). Las competencias emocionales. Educación XXI, 10, 61-82. https://doi.org/10.5944/educxx1.1.10.297 
[37] Seisdedos, N. (1990). STAIC, Cuestionario de Autoevaluación. Madrid: TEA Ediciones S.A.

[38] Spielberger, C. D., Edwards, C. D., Lushene, R., Montuori, J., \& Platzek, D. (1973). The State-Trait Anxiety Inventory for Children. Palo Alto, CA: Mind Garden.

[39] Perez-Escoda,N., Álvarez,M., \& Bisquerra, R. (2008). Qüestionari de desenvolupament emocional per a educació secundària QDE-SEC. Document d'us intern. GROP. Universitat de Barcelona.

[40] Spielberger, C. D., Gorsuch, R. L., \& Lushene, R. E. (1970). Manual for the state-trait anxiety inventory. Palo Alto: Consulting Psychologists Press.

[41] Beck, A. (1979). Cognitive Therapy of Depression. New York: The Guillford Press.

[42] Davidson, R. (2012). El perfil emocional de tu cerebro. Barcelona: Destino.

[43] Pérez-Escoda, N., Torrado, M., López-Cassà,E. \& Fernández Arranz, M. (2014). Competencias emocionales y ansiedad en la educación primaria. I Congreso Internacional de Educación Emocional (X Jornadas de Educación Emocional), Barcelona, 4-6 abril.

[44] Boyd, C., Kostanski, M., Guillone, E., Ollendich, T., \& Shek, D. (2000). Prevalence of anxiety and depression in Australian adolescents: comparisons with worlwide date. Genetic Psychology, 161 (4), 479-92. https://doi.org/10.1080/00221320009596726

[45] Neil, A. \& Christensen, H. (2009). Efficacy and effectiveness of school-based prevention and early intervention programs for anxiety. Clinical Psychology Review, 29(3), 208-215. https://doi.org/10.1016/j.cpr.2009.01.002

\section{Authors}

Agnès Ros-Morente is a doctor in Psychology and Psychopedagogue. She is a lecturer and researcher in the University of Lleida and has developed her expertise in emotional competences and emotion regulation with professor Gemma Filella. Address: University of Lleida, Department of Pedagogy and Psychology. Faculty of Education, Psychology and Social Work. Avenue of Estudi General, 4. 25001. Lleida (Spain).

Enric Cabello is a research assistant with a wide experience in the field of emotional education. He has been working with both adults and children in the Social Welfare Department and his research work has been supervised by dr. Gemma Filella. Address: University of Lleida, Department of Pedagogy and Psychology. Faculty of Education, Psychology and Social Work. Avenue of Estudi General, 4. 25001. Lleida (Spain).

Gemma Filella is a full-time professor in the University of Lleida. She is the director of the GROP-Lleida (Group of Psychopedagogic Orientation) and has been working in emotional education for more than 18 years. Additionally, her expertise in the field, was consolidated with the design, application and evaluation of the Happy videogames. At this moment, she is considered as a key figure in the matter in Spain as well as in Europe. Address: University of Lleida, Department of Pedagogy and Psychology. Faculty of Education, Psychology and Social Work. Avenue of Estudi General, 4. 25001. Lleida (Spain).

Article submitted 16 October 2018. Resubmitted 18 January 2018. Final acceptance 02 February 2018. Final version published as submitted by the authors. 